University of California, Hastings College of the Law UC Hastings Scholarship Repository

Faculty Scholarship

2010

\title{
State of Emergency California's Correctional Crisis
}

\author{
Aaron J. Rappaport \\ UC Hastings College of the Law, rappapor@uchastings.edu \\ Kara Dansky
}

Follow this and additional works at: https://repository.uchastings.edu/faculty_scholarship

\section{Recommended Citation}

Aaron J. Rappaport and Kara Dansky, State of Emergency California's Correctional Crisis, 22 Federal Sentencing Reporter 133 (2010). Available at: https://repository.uchastings.edu/faculty_scholarship/1165

This Article is brought to you for free and open access by UC Hastings Scholarship Repository. It has been accepted for inclusion in Faculty Scholarship by an authorized administrator of UC Hastings Scholarship Repository. For more information, please contact wangangela@uchastings.edu. 


\title{
EDITORS' OBSERVATIONS
}

\section{State of Emergency: California's Correctional Crisis}

\author{
AARON RAPPAPORT \\ Professor of Law, U.C. Hastings College of Law \\ Editor Emeritus, Federal Sentencing Reporter
}

\section{KARA DANSKY}

Executive Director, Stanford Criminal Justice Center

California's reputation has been badly tarnished in recent years by news of the state's persistent legislative gridlock and political dysfunction. Many of these shortcomings can be seen in sharp relief in the state's correctional system-the political pandering, the financial profligacy, the preference for short-term benefits over long-term concerns. These political pathologies have led to a correctional system that seems to be on the verge of collapse, marked by irrational sentencing rules, overcrowded prisons, and a widespread public distrust of the criminal justice system.

That view is widely shared. Numerous studies have warned that California's correctional system is on an unsustainable path. ${ }^{\mathrm{I}}$ In 2006, the governor himself declared a state of emergency for California prisons. ${ }^{2}$ The normally dispassionate think tank the Little Hoover Commission captured the growing sense of urgency in the state when it issued its influential 2007 report, Solving California's Correctional Crisis: Time Is Running Out.

Given the depth of the problems, as well as the state's notorious political paralysis, one might doubt that California can reform its correctional policies. And yet, two forces have come together in a way that makes reform a real possibility. The first is California's fiscal crisis: With burgeoning budget deficits, the state has no choice but to cut back on spending. The massive correctional system, now commanding just over 8 percent of the state general fund, is one of the few discretionary sources available to be cut.

The second force pushing for reform is recent federal litigation over the conditions of California prisons. That litigation, discussed in more detail subsequently, has culminated in a court order requiring California to reduce its prison population (currently around 167,000 ) by approximately 40,000 inmates. The order has, in effect, made sentencing and correctional reform mandatory. Whether legislators like it or not, change is coming to California corrections.

This special issue of Federal Sentencing Reporter brings together an extraordinary group of experts to examine the key challenges facing California's correctional system and to suggest possible ways forward. The articles, taken as a whole, make clear that small modifications to California's existing sentencing and correctional structures will not be sufficient. Wide-ranging reform will be necessary if California is to create a criminal justice system worthy of its name. Fortunately, the broad outlines of a reform project are starting to come into view, and in some areas the state has already begun to move forward. The articles in this issue take a look at several key areas of reform-in sentencing, probation, parole, and prison conditions - that must be addressed if the state is to create a fair and effective criminal justice system.

\section{Reforming California's Correctional System}

\section{A. Sentencing Reform}

For several decades, California's sentencing system has been criticized for being excessively punitive, unduly complex, and in many ways strikingly irrational. One of the complexities of the system is that

Federal Sentencing Reporter, Vol. 22, No. 3, pp. 133-143, ISSN $1053-9867$ electronic ISSN $1533-8363$. (C) 2oIo Vera Institute of Justice. All rights reserved. Please direct requests for permission to photocopy or reproduce article content through the University of California Press's Rights and Permissions website, http://www.ucpressjournals.com/reprintInfo.asp. DOI: 10.1525/fsr.2010.22.3.133.

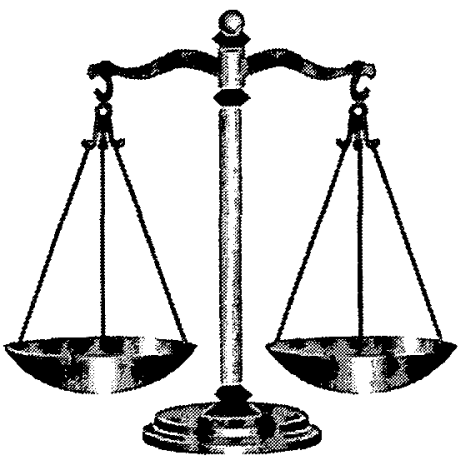


it actually consists of two different sentencing schemes-a determinate sentencing structure and an indeterminate law. Each suffers from distinct shortcomings.

1. The Determinate Sentencing Law The vast majority of offenders in California are sentenced under the state's Determinate Sentencing Law (DSL), enacted in 1976 . The determinate system sets out a series of rules for determining an offender's sentence. Once a sentence is imposed, the offender must serve the entire term (minus any good time credits). Shortcomings in the system, however, are well recognized.

One is the extraordinary complexity of the system. As Judge Couzens points out in his article, "California has an extraordinarily convoluted patchwork body of sentencing laws whose complexity serves as a trap for even the most experienced, diligent, and knowledgeable practitioner." Judge Perren, another contributor to this issue, concurs:

The accused rarely understands the sentencing process; regrettably, the judge, the prosecutor, and defense counsel often show that they are less than fluent in its application. Moreover, the sentencing rules interact in ways that often defy logic, so that the current law has become a hodge-podge of punishments and procedures whose objective is often lost in the arithmetic computation. 4

Criticism such as these have led to numerous efforts to reform the DSL. The leading proposals focus on replacing the DSL with a sentencing commission and guideline system. Such a system, it is hoped, would be able to rationalize California's convoluted sentencing laws and ensure that its correctional resources are used in a way that maximize public safety.

However, repeated efforts to enact such a proposal have, thus far, come to naught. In her fascinating article, Carole D'Elia, deputy executive director of the Little Hoover Commission, describes the frustrating and painful failure of reformers to adopt such a measure in 2007 and 2009 . Despite these losses, efforts to enact a sentencing guideline system will no doubt return in 2010 . One of the questions that proponents of these proposals must address concerns the structure and powers of the Commission. Also in this issue, Kara Dansky, executive director of Stanford's Criminal Justice Center, offers her thoughts on this critical question. She distinguishes between a basic commission, which serves largely an advisory role, and an enhanced commission, which has the power to enact binding sentencing rules. Dansky plainly endorses the latter approach, and offers compelling reasons for that choice.

Intriguingly, both Perren and Couzens embrace a different approach to reforming the DSL. Although they differ in the details, both argue that the judiciary should be given far greater discretion to determine the appropriate sentence for each offender. Judge Perren outlines a particularly detailed proposal, which would replace the DSL with a set of sentencing classifications. Within those relatively broad ranges, the courts would retain the authority to choose a relevant sentence. Judge Couzens adds several other interesting reforms, including the adoption of a unified system of fines and greater use of evidence-based practices at sentencing-practices that have been shown to be effective in reducing recidivism.

2. California's Indeterminate Sentencing Framework In addition to offenders sentenced under the DSL, a number of the most serious and repeat offenders are sentenced to indeterminate life terms, which include sentences of fifteen years to life and twenty-five years to life. Those falling under such sentences comprise a large and growing segment of California's prison population. In 2009 , approximately 32,000 inmates in the state's prison system were serving indeterminate life terms, roughly one fifth of the entire prison population and the highest proportion of lifer inmates of any state in the United States. 5

Perhaps the most well-known and controversial group of lifers is California's three strike offenders, who are sentenced to an indeterminate term of twenty-five years to life in prison. Commentators have criticized the breadth of the three strikes provision, which applies to anyone convicted of a felony who has two prior serious or violent offenses. Because the third strike can be any felony, the majority of offenders have been convicted of nonviolent offenses. ${ }^{6}$ Despite widespread recognition of these problems, the political will to reform the three strikes provision has been lacking, and recent efforts to narrow the scope of the bill have faltered. The most promising effort, Proposition 66 , failed by a few percentage points in 2004 .

In the wake of this loss, major reform of the three strikes law is unlikely anytime soon. For that reason, Mike Romano's article in this issue of FSR is timely. Heading Stanford Law School's three 
strikes clinic, Romano looks at sources of judicial discretion that may be used to narrow the scope of the three strikes provision. As Romano notes, California courts have determined that they have the authority to reject three strikes claims when the offender falls outside the spirit of the Three Strikes Law. At the same time, state courts have been noticeably unclear about what sorts of factors go into that calculus. In his article, Romano sketches out the criteria that should guide the courts in identifying which offenders fall outside the scope of the recidivist statute. Although greater judicial efforts in this regard will not be sufficient to correct the worst features of the law, it will go a small way toward ameliorating the excessive harshness of the provision.

\section{B. Parole Reform}

Paralleling the state's sentencing structure, California has adopted two different parole models-one for offenders sentenced to indeterminate life terms and one for those sentenced under the DSL. The two systems operate under very different rules and face different challenges. The lifer parole process today is particularly problematic; reform remains a high priority. Parole under the determinate sentencing system is a somewhat different story: Although serious problems remain, this area is one of a few where the state has begun to institute needed and valuable reforms.

1. Parole for Lifers Offenders sentenced to indeterminate life terms are eligible for parole when they have served the minimum stated term of imprisonment (e.g., for three strike offenders, parole is permissible when they have completed twenty-five years of their twenty-five-to-life sentence, minus any good time credits). To be eligible for parole, offenders must persuade the Board of Parole Hearings (BPH) that they are suitable for release. Until relatively recently, that was the principal hoop inmates had to jump through. But in 1988 , California passed Proposition 89 , which gave the governor authority to review and, if he deemed it necessary, modify the parole board's determination. As a result, lifers must now persuade the governor, in addition to the $\mathrm{BPH}$, that they are suitable for parole.

The standard for determining whether lifers should be released to parole is whether they represent a continuing threat to society. But it is questionable whether the parole system effectively identifies who can be released early. As Thomas Hoffman, former director of the Department of Adult Parole Operations (DAPO), writes in this issue, the BPH is heavily weighted toward law enforcement. Both the Board and the governor are sensitive to political pressures to appear tough on crime and very averse to taking even reasonable chances on returning ex-cons to the community.

The result is that only a tiny percentage of offenders serving indeterminate life terms are ever returned to the community. According to one estimate, BHP granted the petitions of fewer than 300 offenders serving indeterminate sentences in 2008.7 Many of these grants, moreover, were reversed by the governor, so that ultimately fewer than 90 inmates were paroled. ${ }^{8}$ In contrast, during that same year, the California Department of Corrections and Rehabilitation (CDCR) admitted approximately I,000 murderers serving an indeterminate life term (and last year admitted more than 200 three strikes cases) ${ }^{9}$

With those numbers entering prison and so few being released, it is no wonder that California's lifer population has been expanding so quickly. This course is not sustainable. As University of California, Berkeley, Professor of Law Jonathan Simon recently said,

You do the math. With 30,000 , we already have more lifers in the system than there were total prisoners when I started here at Cal as an undergraduate in I977. And by the time I retire, we could easily have 100,000 lifers, who would never get out. That would be a very frightening kind of prison system to try to run.

Perhaps the most important reform that can be made to the lifer parole system is the one least likely to occur-institutional reform. The current institutional structure for determining parole release dates is tainted by political influence. Proposition 89 should be repealed, and the governor's office should be removed from any decision making over indeterminate life terms. ${ }^{10}$ In addition, the $\mathrm{BPH}$ needs to be restructured to establish a more balanced board, and one that is more fully insulated from political pressure.

In addition, the legal standards used to determine when parole is warranted should be reworked. As Carrie Hempel discusses in her contribution to this issue, that standard has been the source of heated litigation. Hempel was one of the lead attorneys in the landmark case In re Lawrence. "The California Supreme Court held in Lawrence that a parole petition cannot be denied based solely on 
the heinousness of the offense of conviction. Rather, the Court said, the BPH or the governor may base a denial-of-parole decision on the circumstances of the conviction offense, or other inmmutable facts, only if those facts support the ultimate conclusion that the inmate continues to pose an unreasonable risk to public safety.

As far as the California Supreme Court is concerned, the relevant inquiry is not merely whether an inmate's crime was especially callous, or shockingly vicious or lethal, but whether the identified facts are probative to the central issue of current dangerousness when considered in light of the full record. Hempel notes that Lawrence has not entirely eliminated controversy in this field, and the governor and state courts have repeatedly clashed over the precise meaning of the Lawrence holding. But the decision represents a small step toward clarifying the standard for release.

2. Parole Under the DSL For offenders sentenced under the DSL, a different set of parole rules applies. Until very recently, all offenders who had served their determinate terms were automatically placed on parole supervision for three years. If a parolee was accused of violating the terms of parole, the BPH would decide whether to revoke his parole and return him to prison. The Board had almost limitless discretion in this area.

These aspects of the California parole system changed in 2009, in large part due to the passage of Senate Bill 18 (S.B. 18). ${ }^{12}$ However, the former system was in place for so long, and wreaked such havoc on the state's correctional apparatus, it is worth describing the previous system in some detail. Thomas Hoffman's article in this issue identifies some of the key shortcomings of that approach.

One widely recognized problem with the system was that it required all offenders to serve threeyear terms, which meant that all offenders sentenced to determinate terms were supervised to at least some degree by the state parole board, whether they represented a serious threat to the community or not. The result was that the state allocated far too many resources to parolees who were not dangerous, drawing away resources from those who needed close attention.

As one commentator observed with respect to the previous system, "California is virtually alone in this practice of combining determinate sentencing and placing all released prisoners on parole. Most other states either have an indeterminate sentencing system, where a discretionary parole board determines release dates, or have a mandatory parole system only for their most serious or risky offenders." ${ }^{\text {I3 }}$ California's approach has an enormous impact on the correctional system:

With a burgeoning prison population, and a three-year parole term for every released offender, it is not surprising that California is supervising far more parolees than any other state. The Bureau of Justice Statistics reports that in 2007, California supervised about 120,000 parolees on any given day, accounting for 15 percent of all parolees in the country. ${ }^{14}$

S.B. I 8 tries to address this concern by creating a class of low- and moderate-risk parolees who will serve administrative or banked parole. As the CDCR explains,

These low-risk parolees will be subject to standard parole search and seizure conditions but will not be subject to traditional parole supervision upon their release from prison. This creates a $\$$ I00 million savings while allowing agents to focus their attention on higher-risk parolees deemed more of a risk to the public. ${ }^{15}$

Although it's too early to assess the success of this change, the reform is clearly going in the right direction.

A second longstanding concern about the pre-2009 parole system is the limited availability of nonprison sanctions for parole violations and the lack of services provided to parolees under supervision. As Hoffman points out, most inmates

face significant obstacles to reintegration: Most have never held a steady job, most have the equivalent of an eighth-grade education, the vast majority are addicted to drugs and/or alcohol, many have a diagnosed mental illness, many have chronic health problems ...., and every one of them will need the human basics of food, shelter, and clothing. ... [I]f communities do not provide returning parolees with services, employment, and alternatives to crime, most will ultimately fail and quickly leave more victims in their path. If any are to succeed, they will need immediate and effective intervention and assistance beginning the day they are released. ${ }^{16}$ 
Under the old system, inmates who failed to comply with the terms of their parole (which was the majority of them) were typically given a prison term of up to one year as a sanction. ${ }^{77}$ "The revocation process," Hoffman writes, "results in approximately 66,000 parole violators being sent through the CDCR reception center process each year. Predictably, these numbers created a staggering workload, with huge economic implications, all through the system in DAPO and in the thirteen CDCR reception centers throughout the state." 18 This process has made a significant contribution to the growth of the California prison population as returning parolees swell the ranks.

Plainly, sending most parole violators to prison-even for relatively minor infractions-is an enormous waste of expensive correctional resources. Furthermore, it is an ineffective use of resources. Because the maximum prison term is twelve months, and offenders can cut this sentence in half through good behavior, most prisoners serve very short sentences, spending an average of approximately four months in prison. ${ }^{19}$ One fifth of the total serve less than one month.

As Joan Petersilia has put it,

Two thirds of all released parolees in California are back in prison within three years, a proportion twice the national average. Due to their high failure rates, parolees account for the bulk of California prison admissions. In 2008, nearly 70,000 parolees were returned to California prisons for parole violations, serving an average prison term of about four months each for those violations.... This catch-and-release system is costly-from both an economic and a public safety standpoint-and is at the root of the state's overcrowding situation. ${ }^{20}$

The state has taken limited steps toward addressing these concerns. S.B. 18 "establishes and expands drug and mental health reentry courts for parolees to receive highly-structured treatment rather than being returned to prison for violations that may be related to those needs. "21 Parolees subject to administrative parole are also nonrevocable; they cannot be returned to prison for violating the terms of their parole. ${ }^{22}$

A third major problem with the old parole system was the almost total lack of standards for determining who should be sanctioned. As Tom Hoffman notes,

The BPH deploys approximately ninety Deputy Commissioners (DCs) all across the state to hear and adjudicate parole violations each and every day. In my opinion, the decisions reached in this environment have relied almost exclusively on the personal discretion of the DCs. The scope of their discretion was most often not well defined or structured. Predictably, this organizational norm resulted in a system that often came to very different conclusions for the same or similar violations committed by parolees with similar criminal histories. ${ }^{23}$

Moreover, given the broad discretion of parole commissioners and the risk-adverse, law enforcement orientation of the Board, it is not surprising that the default position has been to return parole violators to prison.

In 2009, the CDCR introduced the Parole Violation Decision Making Instrument (PVDMI) to address some of these problems. One purpose of the PVDMI is to create a more consistent and fair revocation decision-making system by giving the Board options other than prison for dealing with parole violations. This more nuanced and effective approach gives the Board a range of alternative sanctions to fashion a response appropriate for the given parole violation. ${ }^{24}$

According to Grattet, Petersilia, Lin, and Beckman, application of the PVDMI results in

a score that designates the appropriate violation response level. The response levels range from least intensive (e.g., community programs) to most intensive responses (in-custody drug treatment or return to prison recommendations).... PVDMI is designed to focus California's prison resources on higher-risk parolees while targeting less serious parole violators for communitybased alternatives that address the root sources of their problems. ${ }^{25}$

S.B. I8 expands on this system by requiring application of the PVDMI in all cases under active parole supervision. Thus, for those high-risk parolees being actively supervised, a prison sanction would no longer be automatic response to parole violations.

A further change would be to try to depoliticize the parole revocation decision to a greater degree, by either restructuring the Board or replacing it with another, more politically insulated body. One 
provocative idea would be to require the initial sentencing judge to determine whether parole should be revoked (rather than the Board of Parole Hearings). ${ }^{26}$

In short, California has already begun to implement certain needed reforms of the mandatory parole system. It has focused supervisory resources more carefully on the highest risk offenders, begun to establish some alternative sanctions for parole violators, and developed a set of guidelines for parole revocation decisions. These changes will not address all of the problems with the mandatory parole process, but it is an appropriate and commendable start.

\section{Alternatives to Prison and Probation Reform}

Useful reform must also address concerns about the front end of the correctional system; particularly important in this regard will be California's emerging efforts to change its probation system. This area is highly significant because, as Roger Warren notes, more than three quarters of convicted California felons are placed on probation, amounting to 350,000 felony probationers in California.

In his article, Warren identifies a number of pressure points for California's increasingly troubled probation system. One is diminished resources. Despite its importance, adult probation has largely been neglected by the state of California, where 58 counties operate 58 different probation systems, all funded and administered solely by the counties themselves. This lack of state support, combined with a history of ballot initiatives that have limited localities from raising revenues, has contributed to significant underfunding of probation services. ${ }^{27}$

A second pressure point for California's probation system is its ineffectiveness. The purpose of probation is to sanction offenders without sending them to prison. Yet, as Warren notes, California's probationers fail to satisfy the terms of their probation at a rate that is to percent higher than the national average. A total of 19,000 probationers are revoked to prison every year, constituting 40 percent of all new prison admissions.

Reform efforts have been picking up speed in this area as well, informed in large part by the abundance of research highlighting the need for improvement. An early study was the I990 Blue Ribbon Commission on Inmate Population Management, which recommended that California develop and expand a program of community-based sanctions for targeted offenders. In 2000 , the Judicial Coucil and the California Association of Counties established the Probation Services Task Force, which urged greater state funding (and involvement) in state probation services. In 2007 , California's Little Hoover Commission called on the state to reallocate its resources and establish a continuum of community-based sanctions.

Warren explains how these efforts eventually culminated in the 2009 passage of S.B. 678 , a bill to reform California's probation services. ${ }^{28}$ The laudable goal of this law is to resuscitate California's anemic community corrections program by funding county probation departments to employ risk. assessment tools and provide evidence-based rehabilitation programs. Warren discusses how this proposal represents a sea change in the state's approach to probation and promises significant benefits in the operation and success of the probation system. At the same time, he cautions readers that the success of the program will depend on the leadership of county probation leaders and courts.

\section{Prison Conditions}

The final key component of any correctional reform effort must focus on the conditions of California prisons. As a result of excessively severe sentencing laws, malfunctioning parole and probation rules, and a lack of resources to fund new prison construction, the state's prisons have become severely overcrowded, now operating at nearly 200 percent of their capacity. That overcrowding has led to a series of metastasizing problems. ${ }^{29}$

It has led, for example, to increased violence in California's prison system. In a 2009 court order, a federal court found that overcrowding made inmate-on-inmate violence "almost impossible to prevent." 30 Inmates are not the only ones affected by the potential for violence created by overcrowded conditions, however. Overcrowding jeopardizes the safety of correctional officers as well; according to the California Correctional Peace Officers Association, nine officers are assaulted every day in California prisons as a result of overcrowding. ${ }^{31}$

Overcrowding has also made it impossible for the state to provide constitutionally adequate mental and medical health care for inmates. In I991, a class of mentally ill prisoners filed a civil rights action claiming that the mental health care provided in California prisons was constitutionally inadequate (Coleman v. Schwarzenegger)..$^{32}$ In 2001 , another class action was filed challenging the constitutionality of the prison medical care system generally (Plata v. Schwarzenegger). ${ }^{33}$ 
Donald Specter, director of the Prison Law Office and lead attorney in Plata, describes in his article the path of the litigation through the federal court system. In each case, the court determined early on that the plaintiff class successfully established a constituitonal violation, reflecting a "near unanimity between correctional experts, California prison administrators, the correctional officers' union, the Governor of California, and various commissions that have studied the situation over the last two decades that this level of overcrowding causes serious and at times deadly harm to prisoners, prison staff, and the public." 34

Having found constitutional violations, however, the judges in both cases struggled to fashion effective remedies. Early on, the Coleman court appointed a special master to monitor the state's attempts to reform the mental health care system, and followed that action with a series of orders mandating remedial action by the state. The state failed to comply with the majority of those orders. Even more dramatically, in 2006 the Plata court placed the entire prison medical system under receivership.

These steps proved to be insufficient, however, because California seemed unable to make even incremental steps toward improvement. In 2007, the plaintiff classes filed a joint motion to appoint a three-judge panel to address the issues of whether prison overcrowding was the primary cause of the unconstitutional conditions and whether a prison population release order was necessary to bring the systems into compliance with the constitution.

As Donald Specter explains, the motion was ultimately granted and two years later, the plaintiff classes got the remedy they sought-a remarkable order by the three-judge panel to reduce the prison population by 40,000 inmates within two years. In its 184 -page ruling, the court found that overcrowding was the primary cause of the unconstitutional conditions, that no relief other than a prison release order would remedy the constitutional violation, that the order was narrowly tailored to bring about the relief sought, and that the order would not result in unacceptable threats to public safety. The court required the state to produce a plan for complying with its order within thirty days.

On its second attempt, the state did come up with a plan for reducing its prison population by 40,000 inmates, but in the meantime it has appealed the court's prison release order. If the order is left undisturbed, California will have no choice but to make significant changes in its criminal justice system; the state cannot possibly comply with the order without reworking the sentencing, parole, and probation laws now on the books.

Still, a large-scale reduction in the state prison population will not itself resolve all of the problems in California's correctional system. One of these is the sheer cost of operating prisons in the state of California. As Grattet et al. have reported, "In 2006-2007, the average annual cost of housing a California prisoner in was $\$ 43,287,1.6$ times higher than the national average of about \$26,000." This amount is a 140 percent increase over per capita spending in 1998.35

Part of this increase is due to reductions in the staff-per-inmate ratio. Since 1998, cost per staffperson has risen by more than $\$ 62,000$, or about 77 percent, because of correctional officer salaries and benefits (including pensions), overtime payments, and the higher costs of medical personnel. The California Legislative Analyst's Office estimates that since 2000, salary increases have added more than \$I billion to the corrections budget.

In her article, Joan Petersilia discusses the role of California prison guards' union in these developments:

Gov. Schwarzenegger made a commitment to reform California's correctional system early in his administration. During his campaign, he vowed to clean up special-interest politics in state government, and on the campaign trail he often mentioned the California Correctional Peace Officers Association (CCPOA), the prison guards' union, as one of the powerful special interests he would tackle if elected. His explicit reference to the overreaching influence of the CCPOA, as well as his own refusal to accept campaign donations from the association, reflected a shift in California gubernatorial politics. Incumbent Gov. Davis had received more than $\$ 3$ million in campaign contributions from CCPOA and allegedly used his political connections to pass a favorable labor contract for them in 2002 . California's prison guards receive the highest salary and benefits among their peers in the nation. ${ }^{36}$

The high cost of California's prisons will continue to squeeze out other needs, programs, and services. Among the most important are rehabilitative services to inmates. Drug treatment, vocational training, and other services have all been drastically cut in recent years, even as prison populations have soared. Even with a reduced prison population, the need for these services will likely outstrip their availability - which means that many former inmates will eventually return to prison anyway. 
If California hopes to reduce both its prison population and its recidivism rate, it will have to find a way to better prepare its offenders to reenter society.

\section{The Schwarzenegger Administration and Beyond}

The record of correctional reform under the Schwarzenegger administration has been mixed at best. As Joan Petersilia notes, in her fascinating review of the Governor's tenure, his administration has achieved certain notable successes over the past few years. It has, for example, made important changes to the mandatory parole system to ensure that supervision is focused on the most serious offenders, and it has increased funding for county probation services through S.B. 678.37

These changes deserve commendation. But the Schwarzenegger administration's record on the whole remains a disappointment for many commentators. In part, this disappointment reflects the hopes that Governor Schwarzenegger engendered at the start of his term. Early in his tenure, the Governor acknowledged that the correctional system he inherited was in terrible shape and in need of wide-ranging reform. Indeed, as Joan Petersilia notes, the Governor made a series of public statements that suggested he would make correctional reform a priority: He promised to freeze prison building, reduce the prison population, expand prison rehabilitation services, and transform the state's sentencing system. But in each case, Schwarzenegger ultimately backed away from those promises, or was forced to alter his plans dramatically.

Joan Petersilia describes how Schwarzenegger quickly abandoned his 2004 pledge of "no new prisons." He not only "opened up the state's thirty-third prison in the Central Valley city of Delano just a year later" but also, under tremendous pressure to relieve overcrowding without seeming soft on crime, he signed AB900, which "provided \$7.7 billion to add 53,000 state prison and county jail beds, the largest single prison construction program in California history. ${ }^{38}$

Schwarzenegger's promise to expand rehabilitation services fared little better. Although the Governor did change the name of the Department of Corrections to the Department of Corrections and Rehabilitation, he did little more. As Petersilia notes, he not only failed to increase funds for work and treatment programs but also, as part of the 2009-2010 state budget, required that prison officials "cut \$250 million from rehabilitation and education services." In this regard, Schwarzenegger must also bear responsibility for the state's persistent recalcitrance in fixing the constitutionally inadequate medical and mental health care services in the prison system (as required by court order in Coleman and Plata). ${ }^{39}$

Governor Schwarzenegger's record on sentencing reform is more mixed. To his credit, he publically and repeatedly endorsed the creation of a sentencing commission to rewrite the state's sentencing laws. The Governor seemed on the verge of passing that proposal in the last budget cycle, but he was ultimately defeated when the Assembly dropped the commission idea. As D'Elia notes in her article, Schwarzenegger responded angrily to the defeat, commenting that lawmakers were more worried about "safe seats" than "safe streets." In this case, politics, rather than a change of administration policy, undermined the reform effort.

Of all the Governor's failures, the inability to reduce California's prison population is probably one of the most disappointing. Doing so would have addressed the overcrowding crisis in the state prison system while also achieving immediate budgetary benefits. Moreover, proposals to achieve significant reductions were readily available.

Expert commissions (such as the Deukmejian Commission) and the Legislative Analyst's Office have for several years listed reforms that would reduce the prison population by tens of thousands. The Governor, however, failed to press ahead with those reforms. To the contrary, on several occasions, Governor Schwarzenegger abandoned promising proposals when faced with political pressure. Joan Petersilia describes how "the Governor backed off from his proposal to place 4,500 low-risk, nonviolent female prisoners in community correctional facilities closer to their families." Petersilia also notes, "This program was a missed opportunity to implement an evidence-based and cost-effective intervention." 40

The Schwarzenegger administration seemed to get serious about reducing the state's prison population only when ordered to release 40,000 inmates by the federal courts in the Plata and the Coleman litigations. Even then, its efforts were hesitant and inconsistent. Less than two weeks after the Court issued its inmate release order on August 4, 2009. California Secretary of Prisons Matthew Cate announced that the administration had developed measures to reduce the prison population by 37,000 over two years, in order to avoid a court-ordered release of prisoners. As Donald Specter states in his article, "The proposed reforms-enhancing good time credits, parole reform, 
diversion of low-risk offenders, and reducing some property crimes to misdemeanors-were similar to those that the court found effective and safe." ${ }^{41}$

Those proposals, however, were not enacted. Specter notes, "The state legislature passed a watered-down version that ultimately is expected to reduce the prison population by approximately II,000 prisoners." 42 Backing down from a political fight, Governor Schwarzenegger then submitted a plan to the Court that would reduce the prison population by 18,000 within two years. Specter describes what happened next:

After the prisoners moved to hold the Governor in civil and criminal contempt, the court rejected the Governor's plan, implied that it would initiate contempt proceedings absent compliance with its orders, and directed the Governor to submit a plan consistent with its original order. The Governor blinked, perhaps motivated by the threat of contempt, and submitted a responsible plan [which] relies on a mixture of measures that include sentencing reform, the transfer of prisoners to private out-of-state and federal immigration facilities, parole reform, community corrections, and enhanced conduct credits. The largest single reduction ( 28 percent of the total) would be accomplished by abolishing state prison sentences for seven drug and property crime. 43

The Governor's tenure, in short, started with enormous promise but ended with only limited and partial success. That record, no doubt, illuminates the extraordinarily difficult political environment for criminal justice reform in California. The Schwarzenegger administration's successes were primarily in areas that are not easily characterized as soft-on-crime initiatives. They involved, for example, focusing parole resources on the most dangerous offenders and trying to increase state funding for probation services. In contrast, proposals that might lead to more expenditures on inmates (such as expanded rehabilitative services) or that might lead to the release of inmates (such as sentencing reform) quickly became too toxic to touch.

If there is a lesson to be learned here, it is that real reform will have a chance of success in California only if the state's next governor is willing to expend significant political capital to institute changes that might appear to be soft on crime. Given the limited political benefits and grave political risks of pursuing such a course, it is hard to be optimistic that a politician in the coming years would be willing to pay those costs. Indeed, one has a sense that well-intentioned politicians-including perhaps Governor Schwarzenegger himself-would almost prefer for the courts to step in and force the state to do the right thing. Earlier in his administration, Schwarzenegger candidly admitted:

I don't blame the courts for stepping in. We tried to solve the health care crisis that we have ... the overcrowding crisis that we have. The fact of the matter is for decades, the state of California hasn't really taken it seriously, hasn't really done something about it.44

This observation is, no doubt, a sad statement about California's democratic process. But so be it. With the political process unable to make reforms, the task of cleaning up the system turns to the courts. And court intervention, it must be said, is better than nothing.

\section{Notes}

I See, e.g., Corrections Independent Review Panel, Reforming Corrections (2004), Joan Petersilia, Understanding California Corrections (2006); California Department of Corrections and Rehabilitation Expert Panel on Adult Offender and Recidivism Reduction Programming, A Roadmap for Effective Offender Programming in California (2007), Kara Dansky, Understanding California Sentencing, 43 U.S.F. L. REv. 45 (2008).

2 See Coleman v. Schwarzenegger, 2009 U.S. Dist. LEXIS 67943, at *114 (E.D. Cal. Aug. 4, 2009) (discussing Governor Schwarzenegger's Emergency Proclamation).

3 J. Richard Couzens, Reforming California's Sentencing Laws: A Judicial Perspective, 22.3 FED. SENT. REP. 154157 (2010).

4 Steven Z. Perren, Indeterminate Sentencing Redux: A Return to Rational Sentencing 22.3 Fed. Sent. ReP. 165-170 (2010). See also Carole D'Elia, The Politics of Public Safety Reform in California, 22.3 FED. SENT. REP. 144-147 (2010) ("What initially was a fairly straightforward sentencing structure has been incrementally and radically rewritten with no consistent or informed evaluation of the laws for their effect on public safety or the state treasury.").

5 See Estimates and Statistical Analysis Section Data Analysis Unit, Offender Information Services Branch, California Department of Corrections and Rehabilitation (hereinafter CDCR), Prison Census Data (as of December 31,2009), Table 10.

6 As of December 31, 2009, 46 percent of third strike commitments were for crimes against persons; the rest were for drug, property, and other crimes. Within the crimes against persons category, the vast majority 
(77\%) were assault and robbery; only 3 percent were homicides. Of those serving third strike life terms in drug cases, 76 percent were for possession. Estimates and Statistical Analysis Section Data Analysis Unit, Offender Information Services Branch, CDCR. Second and Third Striker Felons in the Adult Institution Population: December 31, 2009 (January 2010).

7 These estimates are based on data compiled by the victim's rights advocacy group, Crime Victim's Action Alliance; see http://www.cvactionalliance.com/wordpress/?page_id=19 (last visited April 4, 2009). We have not confirmed these results, but the Stanford Criminal Justice Center has embarked on a project to examine the effect of legal changes on parole grants for offenders serving indeterminate sentences.

8 According to Crime Victim's Action Alliance, Governor Schwarzenegger has been more willing to release parolees than prior governors. In the fourteen years of the previous administrations, Governor Davis and Governor Wilson granted parole in a total of 140 cases (out of 550 that the Parole Board sent to them).

9 During calendar year 2008, 573 offenders were admitted for murder in the first degree and 643 for murder in the second degree. See Estimates and Statistical Analysis Section Data Analysis Unit, Offender Informa. tion Services Branch, CDCR, Characteristics of Felon New Admissions and Parole Violators Returned with a New Term (Calendar Year 2008). The number of offenders sentenced to three strikes in 2009 was 210 (2008 numbers are not readily available). See Estimates and Statistical Analysis Section Data Analysis Unit, Offender Information Services Branch, CDCR, Second and Third Striker Felons in the Adult Institution Population (December 31, 2009). A very small fraction of the three strikers are likely to be second degree murderers.

10 The size and shape of the governor's role in making prison release decisions has been a matter of some controversy since California's founding. The pardon power was one of only two criminal justice issues debated during the 1849 constitutional convention (the other being the death penalty), when California's first lawmakers decided that governors should be permitted to pardon convicted offenders but not to com. mute their sentences. Governors exercised the pardon power with increasing frequency during the $1860 \mathrm{~s}$ and 1870 s as a mechanism for reducing excessively long and disparate prison sentences and for relieving prison overcrowding, but they were often criticized for interfering in the provinces of the other two branches of government. Some have argued that California's first parole law was enacted in response to calls from California governors for the legislature to develop an institutionalized method of early release. See Sheldon $\mathrm{L}$. Messinger et al., The Foundations of Parole in California, 19 LAW \& Soc'y Rev. 69, 70 (1985).

1144 Cal 4th 1181 (2008).

12 S.B. $3 \times 18$ (2009); see infra for discussion of changes caused by S.B. 18.

13 Ryken Grattet, Joan Petersilia, Jeffrey Lin, \& Marlene Beckman, Parole Violations and Revocations in California: Analysis and Suggestions for Action, 73 FED. Probation 1, 2 (2009)

14 ld. at 3.

15 Press Release, CDCR, CDCR Implements Public Safety Reforms to Parole Supervision, Expanded Incentive Credits for Inmates (January 21, 2010), http://www.cdcr.ca.gov/News/2010_Press_Releases/Jan_21.html (last visited April 6, 2010).

16 See Thomas Hoffman, The Debate Around Parole Reform in California, 22.3 Fed. SENT. Rep. 181-185 (2010).

17 Id. (The "vast majority (in excess of $85 \%$ ) of parolees referred to the BPH for a hearing had their parole revoked and were returned to the state institution.").

18 Id. This approach is not, in every case, excessively punitive. In some cases, it is too lenient. Some parolees who have committed serious offenses are sent to the Board of Parole Hearings, rather than retried for criminal violations. Thus, "California parole caseloads likely contain an unusually high proportion of offenders at both extremes of the seriousness continuum-offenders who probably would not be on parole in other states, either because they are too serious to have been released from prison in the first place by parole boards operating in indeterminate states, or because they are such low.risk offenders that they would not have been assigned to post-prison parole supervision at release." Grattet et al., supra note 13 , at 4 .

19 Joan Petersilia, A Retrospective View of Corrections Reform in the Schwarzenegger Administration, 22.3 FED. SENT. REP. 148-153 (2010).

20 Id.

21 CDCR, supra note 15.

22 They can, of course, be returned to prison if they are convicted of a new crime while on parole.

23 Hoffman, supra note 16.

24 For example, as one commentator notes, "Substance abuse-related violations and the violations of parolees with mental health problems make up a large share of all violations. These populations are not well-served by short returns to prison, where the few available service and sanctions are of insufficient duration to improve outcomes." Grattet et al., supra note 13 at 10. The development of alternative community based programs can "both reduce recidivism and save expensive prison beds for the most violent criminals." Id.

25 Grattet et al., supra note 13, at 11. See also Hoffman, supra note 16. ("The PVDMI is designed to bring sci. ence, research, risk assessment, and consistency to the decisions that agents and the BPH reach when responding to parole violations and/or the commission of new crime by a parolee.").

26 That approach has been tried in other states. For example, Washington abolished the practice of revoking offenders to prison entirely in cases where the offender has been sentenced under the determinate sentenc. ing structure (revocation to prison is still possible for offenders sentenced to an indeterminate term). Now, when an offender under community supervision is accused of violating parole, a hearing is scheduled before a judge (not necessarily the sentencing judge, although offenders have the right to request an appearance before their sentencing judges). A judge who finds that the offender has violated the terms of supervision may send the offender to the county jail for a maximum of thirty days per violation. 
27 See Roger K. Warren, Reform in California: Senate Bill 678, 22.3 FED. SENT. Rep. 186-193 (2010) ("California is one of only two states in the nation that does not provide an ongoing stream of funding to support adult probation services. California is also among a dwindling number of states that have no state system of com. munity corrections.").

28 S.B. $3 \times 18$ (2009).

29 Prison overcrowding is not a new phenomenon in California; San Quentin (California's first prison, built in 1852) was overcrowded within a few years of being built. Originally constructed with sixty.two cells, its population had grown to 600 by 1858 , and prison conditions worsened. In its 1859 report, the Board of State Prison Directors complained that "in the present crowded condition of the Prison at San Quentin, no system can be devised for the instruction of these unfortunate men, morally or intellectualiy. . . It is certainly no credit to the State to throw these men back upon society, worse, in all respects, than when they entered the Prison." Board of State Prison Directors, Annual Report for the Year 1859, at 7 (Sacramento, Charles T. Botts 1859).

30 See Coleman v. Schwarzenegger, 2009 U.S. Dist. LEXIS 67943, at *40 (E.D. Cal. Aug. 4, 2009).

31 See http://www.ccpoa.org/issues/ccpoa_on_prison_reform.

32 Coleman v. Schwarzenegger, 2:90-cv-00520-LKK.JFM (E.D. Cal).

33 Plata v. Schwarzenegger, 3:01-cv.01351-TEH (N.D. Cal.).

34 Donald Specter, Everything Revolves Around Overcrowding: The State of California's Prisons, 22.3 FED. SENT. REP. 194-199 (2010).

35 Grattet et al., supra note 13 at 2.

36 Petersilia, supra note 19.

37 The administration has also made significant efforts to reduce the incarceration of juveniles in the state system. Petersilia calis this policy change dramatic and suggests that "the perceived success of the depopu. lation of youth in state facilities influenced subsequent legislation on parole and probation reform." Petersilia, supra note 19.

38 Petersitia, supra note 19

39 This state of affairs is a tragedy. As Petersilia points out, "California's Expert Panel Report found that fewer than 10 percent of all prisoners participated in a substance abuse program while in prison, despite the fact that 80 percent of them had substance abuse histories. With these cuts, the number and quality of rehabilitation programs will be further reduced. These program cuts are particularly disheartening because these are the exact same evidence-based programs that CDCR increased over the last two years; a large body of scientific evidence has shown that these programs save money in the long run by reducing recidivism." $/ d$.

40 Petersilia, supra note 19.

41 Specter, supra note 34.

42 ld.

43 ld.

44 N. Miranda, Overcrowding Could Lead to CA Prison Cap, KGO.TV/DT, http://abclocal.go.com/kgo/story? section $=$ news $/$ politics\&id $=5673478$ (last visited April 8, 2010). 